\title{
The Influence of Technological Inputs on Yield and Quality Traits of Greenhouse Cabbage
}

\author{
Rodica SIMA ${ }^{1)}$, Dănuț MĂNIUȚIU ${ }^{11}$, Alexandru Silviu APAHIDEAN ${ }^{11}$, Maria APAHIDEAN ${ }^{1)}$, Vasile LAZĂR ${ }^{1)}$ \\ and Nicușor SIMA ${ }^{1^{*}}$ \\ 1)University of Agricultural Sciences and Veterinary Medicine Cluj-Napoca, Romania. \\ ${ }^{*}$ Coresponding author, e-mail: flaviusima@yahoo.com
}

Bulletin UASVM Horticulture 71(2) / 2014

Print ISSN 1843-5254, Electronic ISSN 1843-5394

DOI:10.15835/buasvmcn-hort:10834

\begin{abstract}
Cabbage is among the vegetables which can be found on the market throughout the year, greenhouse crop being a source of fresh cabbage in the cold season. The aim of this experiment was to study the influence of planting density/plant spacing and additional fertilization on the yield and quality traits of greenhouse cabbage. The low plant spacing $(50 \times 25 \mathrm{~cm})$ revealed the highest yields regardless the applied additional fertilization. Foliar fertilization with Ferticare (24:8:16) as split applications during all growing season, provided the highest marketable head weight, as well as the highest vitamin $\mathrm{C}$ content and total soluble solids content of cabbage heads.
\end{abstract}

Keywords: fertilization, head cabbage, planting density, quality

\section{INTRODUCTION}

Head cabbage is an important source of carbohydrates, minerals, vitamins and volatile substances with antibacterial properties. Cabbage belongs to the group of vegetables high in vitamin C (Gould et al., 2006) and antioxidant potential (Nilsson et al., 2006). Greenhouse crops provide market with fresh cabbage in the cold season. The importance of cultivar in obtaining of high quantitative and qualitative yields with cabbage crops was emphasized by Poșta and Berar (2006). The head cabbage is a crop with high nutrient requirements to the nitrogen as well as potassium and phosphorus because it accumulates large vegetative biomass in a relatively short period (Atanasova et al., 2007). Besides cultivar and a balanced mineral nutrition, planting density is a very important factor which influences the yield and quality of head cabbage. Increasing planting density in cabbage crop has the potential for increasing yield and profit (Znidarcic et al., 2007). Moniruzzaman (2011) also shown that dense planting of cabbage seedling can produce higher head yield owing to the presence of more number of plants per unit area, although they produce smaller heads irrespective of varieties. The present study was undertaken to evaluate the influence of additional fertilization and two plant spacings on the head yield and head quality of an early cabbage cultivar recommended for greenhouse crops.

\section{MATERIALS AND METHODS}

The research has been carried out in the greenhouses of Vegetable growing Department of UASVM Cluj-Napoca during January-April months, in 2011. The experiment was bifactorial and organized within a complete randomized block design with three replications. Tiara F1 white cabbage was used as biological material. Experimental factors were represented by planting density/plant spacing and additional fertilization. The studied planting densities $\left(62,500 \mathrm{pl} \mathrm{ha}^{-1}\right.$ and $81,250 \mathrm{pl} \mathrm{ha}^{-1}$ ) resulted from a constant distance between rows of $50 \mathrm{~cm}$ and from 30 $\mathrm{cm}$, respectively $25 \mathrm{~cm}$ spacing within row. Each experimental plot had $9.6 \mathrm{~m}^{-2}$ and consisted of 60 plants respectively 78 plants according to the studied plant spacing. Seeding was done in cel 
trays in November 2010, transplanting in $10 \mathrm{~cm}$ diameter pots in December 2010 and planting of seedlings in the greenhouse soil in the end of January 2011. Base fertilization was done with 300 kg ha-1 Complex III 15-15-15 NPK locally applied at seedlings planting time for all experimental variants. Additional fertilization comprised the split application of fertilizers with following doses and time of application: 1 . unfertilized control; $2.100 \mathrm{~kg} \mathrm{ha}^{-1}$ Complex III as topdressing during head formation; 3. $200 \mathrm{~kg} \mathrm{ha}^{-1}$ Complex III as topdressing during head formation; $4.1 \%$ solution of Ferticare (24:8:16) as foliar sprayings started at the beginning of intensive leaves growth and conducted all growing season at two weeks interval. Harvesting started in the beginning of April when the cultivar appeared to approach the technical maturity by the visual criteria. For each experimental variant samples of 9 heads were taken in order to determine the rosette diameter, the head weight, the head polar diameter and the number of leaves within head. Other samples of 3 heads per variant were cut and split longitudinally in order to measure the core length and to take fresh matter samples for vitamin C, acidity, soluble solids and dry matter determinations. Vitamin $\mathrm{C}$ was determined by the iodate method and acidity by the titrimetric method, being expressed as malic acid. The total soluble solids was determined with a Zeiss portable refractometer and the dry matter by drying of fresh matter samples for $48 \mathrm{~h}$ at $60^{\circ} \mathrm{C}$ in a drying oven.

\section{RESULTS AND DISCUSSION}

Among the important factors which can influence the yields of greenhouse cabbage crops, the balanced fertilization and the use of proper planting density play an important role. In this trial plant spacing revealed significant effect on the obtained yield. Thus, as whitin row spacing decresed (from $30 \mathrm{~cm}$ to $25 \mathrm{~cm}$ ), the obtained yield increased (Tab. 1), the increase being statistically distinct significant in comparison with control (high plant spacing). The obtained results are in agreement with the findings of Znidarcic, 2007.

The highest cabbage yield (49.63 th ha $\left.{ }^{-1}\right)$ was obtained in the variant with foliar fertilization. Besides its nutritive contribution, foliar fertilization can determine a better utilization of radicular applied mineral fertilizers, as base fertilization, in the specific greenhouse agricultural fund conditions. Very significant yield increase (3.34 $\mathrm{kg} \cdot \mathrm{ha}^{-1}$ ) was also revealed with split application of mineral fertilizers, in moderate dose of $100 \mathrm{~kg} \cdot \mathrm{ha}^{-1}$, during head formation. However, statistically significant increases of yields in comparison with control were obtained with all fertilization treatments (Tab. 2).

Tab. 1. Variation with density in the yield of greenhouse cabbage crop

\begin{tabular}{lcccc}
\hline Planting density/Plant spacing & Yield kg/m $\mathrm{m}^{2}$ & Relative yield \% & 土 Difference & Signification \\
\hline $62,500 \mathrm{pl} \cdot \mathrm{ha}^{-1}(50 \times 30 \mathrm{~cm})$ & 41.85 & 100.0 & 0.00 & Control \\
\hline $81,250 \mathrm{pl} \cdot \mathrm{ha}^{-1}(50 \times 25 \mathrm{~cm})$ & 45.12 & 107.8 & 3.27 & $* *$ \\
\hline LSD (p 5\%) & & & 1.08 \\
LSD (p 1\%) & & & 2.48 & \\
LSD (p 0.1\%) & & & 7.90 &
\end{tabular}

Tab. 2. Variation with fertilization in the yield of greenhouse cabbage crop

\begin{tabular}{lcccc}
\hline \multicolumn{1}{c}{ Additional fertilization } & Yield $\mathrm{kg} \cdot \mathrm{m}^{-2}$ & Relative yield \% & 土 Difference & Signification \\
\hline Unfertilized & 39.91 & 100.0 & 0.00 & Control \\
\hline 100 kg/ha Complex III (N:P:K 15:15:15) & 43.25 & 108.4 & 3.34 & $* * *$ \\
\hline 200 kg/ha Complex III (N:P:K 15:15:15) & 41.16 & 103.1 & 1.25 & $*$ \\
\hline 1\% solution of Ferticare (N:P:K 24:8:16) & 49.63 & 124.4 & 9.72 & $* * *$ \\
\hline LSD (p 5\%) & & & 1.01 & 1.41 \\
LSD (p 1\%) & & & 2.00 & \\
LSD (p 0.1\%) & & & &
\end{tabular}


Increasing of planting density from 62,500 $\mathrm{pl}^{-h^{-1}}$ at $81,250 \mathrm{pl} \cdot \mathrm{ha}^{-1}$ combined with split application of mineral fertilizers (Complex III 100 $\mathrm{kg} \cdot \mathrm{ha}^{-1}$ and $\left.200 \mathrm{~kg} \cdot \mathrm{ha}^{-1}\right)$ or foliar fertilizers (1\% solution of Ferticare) determined very significant yield increases of greenhouse cabbage crop as compared with control - unfertilized variant (Tab. 3 ). It has to be remarked that only in case of split application of foliar fertilizers the obtained yield increased very significantly (between $8.78-12.49$ $\mathrm{kg} \cdot \mathrm{ha}^{-1}$ ), regardless the planting density.

The combined effect of additional fertilization and planting density on the growth characters of cabbage was assessed through the rosette diameter, the polar diameter of head, the marketable head weight, the number of folded leaves and the core length (Tab. 4).

In this experiment the rosette diameter varied between $56.5 \mathrm{~cm}$ and $63.9 \mathrm{~cm}$ and increased with increasing of plant spacing (Tab. 4). Taking into consideration that early cabbage grows in greenhouse in short day conditions it has to develop a width rosette in order to achive an as high as possible photosynthetic area (Cervenski et al., 2012). Maintaining of high plant spacing ( $50 \times 30$ $\mathrm{cm}$ ) provided a better use of solar radiation, water and nutrients resulting in a greater head weight than in the variants with low plant spacing (Tab. 4). In this trial the head weight varied between $527.5 \mathrm{~g}$ and $651.5 \mathrm{~g}$ in low plant spacing variants

Tab. 3. Combined effect of fertilization and planting density on the yield of greenhouse cabbage crop

\begin{tabular}{|c|c|c|c|c|c|c|}
\hline Variant & Planting density & Additional fertilization & $\begin{array}{l}\text { Yield } \\
\mathrm{kg} / \mathrm{m}^{2}\end{array}$ & $\begin{array}{c}\text { Relative } \\
\text { yield } \\
\% \\
\end{array}$ & \pm Difference & Signification \\
\hline V1 & $62,500 \mathrm{pl} \cdot \mathrm{ha}^{-1}$ & \multirow{2}{*}{ Unfertilized } & 38.99 & 100.0 & 0.00 & Control \\
\hline $\mathrm{V} 2$ & $81,250 \mathrm{pl} \cdot \mathrm{ha}^{-1}$ & & 40.82 & 104.7 & 1.83 & $*$ \\
\hline V3 & $62,500 \mathrm{pl} \cdot \mathrm{ha}^{-1}$ & \multirow{2}{*}{$\begin{array}{c}100 \mathrm{~kg} / \text { ha Complex III (N:P:K } \\
\text { 15:15:15) }\end{array}$} & 41.38 & 106.1 & 2.39 & $* *$ \\
\hline V4 & $81,250 \mathrm{pl} \cdot \mathrm{ha}^{-1}$ & & 45.11 & 115.7 & 6.12 & $* * *$ \\
\hline V5 & $62,500 \mathrm{pl} \cdot \mathrm{ha}^{-1}$ & \multirow{2}{*}{$\begin{array}{c}200 \mathrm{~kg} / \mathrm{ha} \text { Complex III (N:P:K } \\
\text { 15:15:15) }\end{array}$} & 39.25 & 100.7 & 0.26 & - \\
\hline V6 & $81,250 \mathrm{pl} \cdot \mathrm{ha}^{-1}$ & & 43.07 & 110.5 & 4.08 & $* * *$ \\
\hline V7 & $62,500 \mathrm{pl} \cdot \mathrm{ha}^{-1}$ & \multirow{2}{*}{$\begin{array}{l}\text { 1\% solution of Ferticare (N:P:K } \\
24: 8: 16)\end{array}$} & 47.77 & 122.5 & 8.78 & $* * *$ \\
\hline V8 & $81,250 \mathrm{pl} \cdot \mathrm{ha}^{-1}$ & & 51.48 & 132.0 & 12.49 & $* * *$ \\
\hline & LSD (p 5\%) & & & & 1.43 & \\
\hline & LSD (p 1\%) & & & & 2.00 & \\
\hline & LSD (p 0.1\%) & & & & 2.82 & \\
\hline
\end{tabular}

Tab. 4. Combined effect of fertilization and planting density on growth characteristics of greenhouse cabbage

\begin{tabular}{|c|c|c|c|c|c|c|c|}
\hline Variant & $\begin{array}{l}\text { Planting } \\
\text { density }\end{array}$ & Additional fertilization & $\begin{array}{l}\text { Rosette } \\
\text { diameter } \\
(\mathrm{cm})\end{array}$ & $\begin{array}{c}\text { Polar } \\
\text { diameter of } \\
\text { head } \\
(\mathrm{cm})\end{array}$ & $\begin{array}{l}\text { Marketable } \\
\text { head weight } \\
\text { (g) }\end{array}$ & $\begin{array}{c}\text { Number } \\
\text { of folded } \\
\text { leaves }\end{array}$ & $\begin{array}{c}\text { Core } \\
\text { length } \\
(\mathrm{cm})\end{array}$ \\
\hline V1 & $\begin{array}{c}62,500 \mathrm{pl} \cdot \mathrm{ha}^{-1} \\
\text { - control }\end{array}$ & \multirow{2}{*}{ Unfertilized - control } & 57.7 & 11.8 & 619.9 & 35 & 6.4 \\
\hline $\mathrm{V} 2$ & $81,250 \mathrm{pl} \cdot \mathrm{ha}^{-1}$ & & 56.5 & 11.9 & 593.8 & 33 & 7.0 \\
\hline V3 & $62,500 \mathrm{pl} \cdot \mathrm{ha}^{-1}$ & \multirow{2}{*}{$\begin{array}{c}100 \mathrm{~kg} / \text { ha Complex III } \\
\text { (N:P:K 15:15:15) }\end{array}$} & 62.0 & 12.1 & 627.4 & 39 & 7.0 \\
\hline V4 & $81,250 \mathrm{pl} \cdot \mathrm{ha}^{-1}$ & & 56.8 & 12.3 & 581.9 & 37 & 8.3 \\
\hline V5 & $62,500 \mathrm{pl} \cdot \mathrm{ha}^{-1}$ & \multirow{2}{*}{$\begin{array}{l}200 \mathrm{~kg} / \text { ha Complex III } \\
\text { (N:P:K 15:15:15) }\end{array}$} & 57.8 & 11.1 & 555.3 & 37 & 6.5 \\
\hline V6 & $81,250 \mathrm{pl} \cdot \mathrm{ha}^{-1}$ & & 57.0 & 11.2 & 527.5 & 33 & 7.3 \\
\hline V7 & $62,500 \mathrm{pl} \cdot \mathrm{ha}^{-1}$ & \multirow{2}{*}{$\begin{array}{l}\text { 1\% solution of Ferticare } \\
\text { (N:P:K 24:8:16) }\end{array}$} & 63.9 & 12.0 & 678.0 & 41 & 7.5 \\
\hline V8 & $81,250 \mathrm{pl} \cdot \mathrm{ha}^{-1}$ & & 61.5 & 12.2 & 651.5 & 39 & 7.8 \\
\hline
\end{tabular}


Tab. 5. Combined effect of fertilization and planting density on quality traits of greenhouse cabbage

\begin{tabular}{|c|c|c|c|c|c|c|c|}
\hline Variant & $\begin{array}{l}\text { Planting } \\
\text { density }\end{array}$ & Additional fertilization & $\begin{array}{c}\text { Vitamina C } \\
(\mathrm{mg} / 100 \mathrm{~g} \\
\text { fresh matter) }\end{array}$ & $\begin{array}{c}\text { Titratable } \\
\text { acidity } \\
\text { (\% malic acid) }\end{array}$ & $\begin{array}{l}\text { Dry } \\
\text { matter } \\
(\%)\end{array}$ & $\begin{array}{l}\text { Soluble } \\
\text { solids } \\
(\%)\end{array}$ & $\begin{array}{c}\text { Insoluble } \\
\text { solids } \\
(\%)\end{array}$ \\
\hline V1 & $\begin{array}{c}62,500 \\
\text { pl-ha }{ }^{-1} \\
- \text { control }\end{array}$ & \multirow[t]{2}{*}{ Unfertilized - control } & 34.85 & 0.15 & 7.0 & 5.05 & 1.95 \\
\hline V2 & $\begin{array}{l}81,250 \\
\mathrm{pl}^{\prime} \cdot \mathrm{ha}^{-1}\end{array}$ & & 26.10 & 0.13 & 6.2 & 5.13 & 1.07 \\
\hline V3 & $\begin{array}{l}62,500 \\
{\text { pl} \cdot h a^{-1}}^{-1}\end{array}$ & \multirow{2}{*}{$\begin{array}{l}100 \mathrm{~kg} / \mathrm{ha} \text { Complex III } \\
\text { (N:P:K 15:15:15) }\end{array}$} & 49.63 & 0.17 & 7.6 & 4.62 & 2.98 \\
\hline V4 & $\begin{array}{l}81,250 \\
\text { pl }^{\prime} \mathrm{ha}^{-1}\end{array}$ & & 33.79 & 0.16 & 7.0 & 5.50 & 1.50 \\
\hline V5 & $\begin{array}{l}62,500 \\
\mathrm{pl}^{\prime} \cdot \mathrm{ha}^{-1}\end{array}$ & \multirow{2}{*}{$\begin{array}{l}200 \text { kg/ha Complex III } \\
\text { (N:P:K 15:15:15) }\end{array}$} & 45.41 & 0.12 & 7.4 & 4.30 & 3.10 \\
\hline V6 & $\begin{array}{l}81,250 \\
\mathrm{pl} \cdot \mathrm{ha}^{-1}\end{array}$ & & 38.72 & 0.10 & 7.0 & 4.56 & 2.44 \\
\hline V7 & $\begin{array}{l}62,500 \\
\text { pl-ha }^{-1}\end{array}$ & \multirow{2}{*}{$\begin{array}{l}\text { 1\% solution of Ferticare } \\
\text { (N:P:K 24:8:16) }\end{array}$} & 44.00 & 0.20 & 7.2 & 5.44 & 1.76 \\
\hline V8 & $\begin{array}{l}81,250 \\
\mathrm{pl} \cdot \mathrm{ha}^{-1}\end{array}$ & & 42.24 & 0.13 & 7.2 & 5.80 & 1.40 \\
\hline
\end{tabular}

and between $555.3 \mathrm{~g}$ and $678.0 \mathrm{~g}$ in high plant spacing variants, the upper values of head weight being obtained with foliar fertilization (Tab. 4). On the other hand there can be observed that the high marketable head weight obtained was not positive correlated with the marketable yield per hectare (Tab. 3). Thus, the greatest head weights resulted from increased plant spacing did not compensate the decresed number of plants per hectare, how was also mentioned by Semuli (2005).

Low plant spacing $(50 \times 25 \mathrm{~cm})$ in this experiment resulted in a lightly increase of polar diameter of head and core length (Tab. 4). Both growth characteristics can be correlated with the increase of obtained yield. Znidarcic et al., (2007) had mentioned that core volume (estimated through con formula by using core length and core base width) was significantly increased by decrease of plant spacing. Cervenski et al., (1998) in their research results have found positive correlations between head weight and head height, respectively between head height and yield.

Increasing of plant spacings in greenhouse cabbage crop increased the number of folded leaves, an important characteristic which influenced the head weight (Tab. 4). Similar results were reported by Moniruzzaman (2011).
Vitamin C (ascorbic acid, AA) represents an important quality factor with antioxidant activity in many vegetables. Among Brassica vegetables, white cabbage is the poorest source of vitamin C (Wlodzimierz et al., 2010). However, in Romania white cabbage is the most cultivated and consumed species among Brassica vegetables, its contribution in human diet being important through the consumed quantity. In this trial the AA content varied between 26.10 and $49.63 \mathrm{mg} / 100$ $\mathrm{g}$ fresh matter, being higher in variants with high plant spacing and, thus, with better influx of solar radiation, than in variants with low plant spacing. Considering the applied fertilization, AA content increased in variant with foliar fertilization, regardless the plant spacing. Similar effect was revealed by Atanasova et al., 2007.

The evolution of the titratable acidity was similar with that of the vitamin C.

The ratios of dry matter, soluble solids and insoluble solids varied with plant spacing and additional fertilization. As a result, the ratio of dry matter of cabbage grown at high spacing was higher than at low spacing while soluble solids was higher in the low plant spacing than in the high plant spacing. It has to be remarked that the maximum total soluble solids and the minimum 
content of insoluble solids, among which cellulose content, were obtained with foliar fertilized variants.

\section{CONCLUSION}

Increasing of planting density in greenhouse cabbage crop determined very significant yield increases through a higher number of heads per unit area, although the reducing of plant spacing conducted to a decrease of marketable head weight.

The highest cabbage yield (49.63 t $\left.\cdot \mathrm{ha}^{-1}\right)$ was obtained in the variant with foliar fertilization, but very significant yield increase $\left(3.34 \mathrm{~kg} \cdot \mathrm{ha}^{-1}\right)$ was also revealed with split application of mineral fertilizers, in moderate dose of $100 \mathrm{~kg} \cdot \mathrm{ha}^{-1}$, during head formation.

The increase of plant spacing in greenhouse cabbage crop increased the number of folded leaves, an important characteristic which influences the marketable head weight.

The maximum total soluble solids and the AA content increased in variant with foliar fertilization.

\section{REFERENCES}

1. Atanasova E, Mitova I, Dimitrov I, Stancheva I (2007). Effects of different fertilizer sources on the quality of head cabbage. Journal of Applied Horticulture 9(1):74-76.

2. Cervenski J, Gvozdenovic DJ, Takac A, Bugarski D (1998). Correlation between some of the yield components of cabbage (Brassica oleracae var. capitata L.). Proceedings of $2^{\text {nd }}$ Balkan Symposium of Field Crops 1:509-513.

3. Cervenski J, Jelica Gvozdanovic-Varga, Svetlana Glogovac (2012). Variance components and correlations of agronomic traits among cabbage (Brassica oleracea var. capitata L.) maturity groups. Genetika 44(1):55-68.

4. Gould S, Tkesslee DK, King CG (2006). Vitamin C content of vegetables, V. Cabbage. J. Food Sci. 1(5):427-434.

5. Moniruzzaman M (2011). Effect of plant spacings on the performance of hybrid cabbage (Brassica oleracea var. capitata) varieties. Bangladesh J. Agril. Res. 36(3):495506.

6. Nilsson J, Olsson $\mathrm{K}$, Engqvist G, Ekvall J, Olsson $\mathrm{M}$, Nyman M, Akesson B (2006). Variation in the content of glucosinolates, hydroxycinnamic acids, carotenoids, total antioxidant capacity and low-molecular-weight carbohydrates in Brassica vegetables. J. Sci. Food Agr. 86:528-538.

7. Poșta Gh, Berar V (2006). Researches concerning the yield performances of the early cabbage hybrids cultivated in the field conditions. Buletin USAMV-CN, 63:388-392.

8. Semuli KLH (2005). Nitrogen requirements for cabbage (Brassica oleracea capitata) transplants and crop response to spacing and nitrogen top-dressing. M. Sc. Thesis, University of Pretoria, $57 \mathrm{p}$.

9. Znidarcic D, Nina Kacjan-Marsic, Osvald J, Pozrl T, Trdan S (2007). Yield and quality of early cabbage (Brassica oleracea L. var. capitata) in response to within-row plant spacing, Acta agriculturae Slovenica 89(1):15-23.

10. Włodzimierz S, Domagałan\&ą̨tkiewicz I, Rożek S (2010). Effect of nitrogen fertilization on sugars, ascorbic acid and phenolic compounds in white cabbage (Brassica oleracea var. capitata alba L.). Acta Sci. Pol., Hortorum Cultus 9(4):41-51. 